\title{
The Seroprevalence of Equine Trypanosomosis in the Pantanal
}

\author{
Alberto MR Dávila/+, Silvana S Souza*, Cristiane Campos**, \\ Roberto Aguilar MS Silva***
}

Laboratório de Sanidade Animal, Embrapa/CPAP, Corumbá, MS, Brasil *DAM/CEUC, Universidade Federal de

Mato Grosso do Sul, Corumbá, MS, Brasil **Departamento de Zootecnia, Universidade Estadual do Mato

Grosso do Sul, Unidade de Aquidauana, Rodovia Aquidauana, Cera, km 12, Aquidauana, MS, Brasil

***Laboratório de Sanidade Animal, Embrapa/Suinos \& Aves, Br 153, km 110, 89700-000,

Concórdia SC, Brasil

Since little information is available on the epizootiological status of Trypanosoma evansi in South America and particularly Brazil, we evaluated equine serum samples collected in 1993, 1994, 1995 and 1997 for the presence of antibodies against this trypanosome species. Our study shows corroborative evidence about the correlation among high $\mathrm{T}$. evansi seroprevalence and the rainy season in the Pantanal, Brazil. The higher seroprevalence was $79.2 \%$ in horses from a ranch located in the Nhecolândia subregion in 1994 and the lower 5.8\% in animals from the same ranch in 1997. No seroprevalence was found in 1993. The possible re-introduction of T. evansi in the region as well as the relationship among our results with the outbreaks reported in 1994, are briefly discussed.

Key words: Trypanosoma evansi - seroprevalence - Pantanal - Brazil

Trypanosoma evansi causes the equine trypanosomosis also called "Mal de Caderas", and is one of the most important protozoan diseases in the Pantanal region of Brazil. T. evansi infects a wide variety of mammals and in the Pantanal has been found in horses, coatis (Nasua nasua), dogs, capybaras (Hydrochaeris hydrochaeris) (Nunes \& Oshiro 1990, Silva et al. 1995b) and small wild rodents (Oryzomys sp.) (Nunes et al. 1995).

In South America, T. evansi affects principally horses which are very important for cattle management, however, it is important to emphasize that cattle raising is the most important economic activity in the Pantanal. Extensive cattle ranches varying from 10,000 to 200,000 hectares occupy most of the Pantanal. It is populated by $3.013,218$ cattle, 4,966 buffaloes and 49,000 horses (Cadavid Garcia 1986, Silva et al. 1998, Seidl et al. 1998). According to Seidl et al. (1998) the estimated total cost of T. evansi to the Pantanal region's cattle ranchers is about US\$2.4 million and 6,462 horses per year.

Supported by Embrapa and CNPq-RHAE.

+Corresponding author: Fax: + 55-21-590.3495. E-mail: davila@gene.dbbm.fiocruz.br. Present address: Laboratório de Biologia Molecular de Tripanosomatídeos, Departamento de Bioquímica e Biologia Molecular, Instituto Oswaldo Cruz, Av. Brasil 4365, 21045-900, Rio de Janeiro, RJ, Brasil.

Received 12 November 1998

Accepted 19 January 1999
Preliminary studies on the prevalence of $T$. evansi in the northern region of the Pantanal have been developed by Franke et al. (1994). They recorded the presence of T. evansi in horses, bovines, dogs and capybaras in the sub-region of Pantanal of Poconé with prevalences of 9.6\%, 4.2\%, $18.6 \%$ and $14 \%$, respectively. These results were obtained using the Ab-Elisa (enzyme-linked immunoabsorbent assay) for detection of antibodies against $T$. evansi.

This paper shows data on the seroprevalence of T. evansi in horses from the Pantanal region of Brazil.

\section{MATERIALS AND METHODS}

Using an immunofluorescent antibody test we evaluated 20 equine serum samples from ranch 1 (R1-Nhecolândia sub-region) collected in January 1993 and other 65 serum samples collected from the ranch 2 (R2-Nabileque sub-region) in February 1994 (manuscript in preparation). Twenty-two sera samples from ranch 3 (R3-Nhecolândia subregion) collected in 1993 (August), 1994 (March) and 1995 (December), as well as other 102 samples collected in July 1997 were analyzed. Twenty samples of ranch 4 (R4-Nabileque sub-region) obtained from the outbreak of 1994 (Silva et al. 1995b) were also tested.

\section{RESULTS}

From the R3 located in the Nhecolândia subregion of the Pantanal we obtained the following 
prevalences: $0,79.2 \%$ and $68 \%$ in the years 1993 , 1994 and 1995, respectively. The prevalence of R1Nhecolândia (January 1993) was zero. On the other hand in R2 and R4 from Nabileque sub-region (February 1994) were $21.5 \%$ and $100 \%$, respectively (Table).

The incidence recorded in R3 was 0, 79.2, 68 and $5.8 \%$ in 1993, 1994, 1995 and 1997, respectively.

\section{DISCUSSION}

Prevalences in R2 and R3 from 1994-1995 (Table) are higher than those recorded in the literature. Franke et al. (1994) found a T. evansi prevalence of $9.6 \%$ in horses from the Pantanal of Poconé sub-region State of Mato Grosso, using an ab-Elisa (Elisa for antibody detection). In Santa Cruz, Bolivia a T. evansi prevalence of $4.41 \%$ using Elisa was recorded in horses (Klarmann-Osuna 1996). On the other hand, in the Formosa province, Argentina the prevalence found was $19.3 \%$ in horses among the years of 1983-1987 (Monzon $\&$ Colman 1988). The low prevalence in this study was $5.8 \%$ in R3 located in the Nhecolândia subregion. Nevertheless, it is similar to the $4.41 \%$ prevalence found in horses from Santa Cruz, Bolivia, considered by the author as a high one (Klarmann-Osuna 1996).

In the present study we have not found indication of T. evansi prevalence in horses from $\mathrm{R} 1$ and R3 (Nhecolândia sub-region) in 1993. This trypanosome was probably introduced in South America during the XVI century by Spanish settlers (Hoare 1972, Santos et al. 1992) and arrived to the Pantanal by 1850 . No effective drug treatment was available until 1930, however, ranchers usually imported horses from other regions because of the high mortality rate caused by this trypanosome. Furthermore, outbreaks of equine trypanosomosis have been informally reported in the Nhecolândia sub-region since 1894 (Barros 1959). However, considering that (a) the first official records of $T$. evansi outbreaks in horses were made in 1994 (Silva et al. 1995b); (b) other researchers did not find T. evansi in horses from the Nhecolândia subregion before 1994 (Stevens et al. 1989), and (c) lack of T. evansi prevalence in 1993 (present study); we believe that this parasite could have been reintroduced in the southern Pantanal in 1994. Factors like increase of cattle movement during the last years, climatic conditions like flooding of the region (Dávila et al. 1997), stress of animals and contact with new $T$. evansi strains could have contributed for the outbreaks of 1994.

There is a temporal association among the raining season and the abundance of tabanids in the Pantanal, but these insects remain in a high number until the end of the rainy season (Silva et al. 1995a). A similar observation has been made in Kenya (Gardiner 1989), Thailand (Lohr et al. 1985), Chad (Gruvel \& Balis 1965) and Bolivia (Bejarano 1996). The latter author concluded that the peak of tabanids coincide with the highest temperature and rainy season in a province of the Santa Cruz department, Bolivia. Since in the Pantanal the dry season is from June-August (Figure), we could think that the lack of prevalence in R3 in August 1993 is due the low number of mechanical inoculators like tabanids. It would be true when parasitological test are used, and we were looking for parasites in the blood of animals. However, in the present study we used a serological test which can detect IgG levels against $T$. evansi. According to Monzón (1986, 1987), serological titters down gradually after treatment and remain circulating for aproximatelly one year. Thus, we should have detected some prevalence in R3 (August 1993), if any, such as done in the same ranch in July 1997, which is also a month belonging to the dry season.

Our study provide corroborative data about the correlation among high prevalences and the rainy season in the Pantanal (Table). The higher prevalence recorded in R3 (Nhecolândia sub-region) in $1994(79.2 \%)$ could correspond to an outbreak. In the same year, from February to July, nine T. evansi outbreaks occurred in the same sub-region as well as neighbors sub-regions as Pantanal of Paraguay, where the first outbreaks of equine trypanosomosis were reported with mortality as high as $51 \%$ (Silva et al. 1995a,b). There probably is a relationship among the outbreaks reported in Nhecolândia and Paraguay sub-regions (Silva et al 1995a) with the

TABLE

Seroprevalence of Trypanosoma evansi in the Nhecolândia and Nabileque sub-regions of the Pantanal, Brazil (\%)

\begin{tabular}{lccccccc}
\hline & \multicolumn{2}{c}{1993} & & & 1994 & 1995 & 1997 \\
\cline { 2 - 7 } & Jan & Aug & Feb & Mar & Dec & Jul \\
\hline R1 - Nhecolândia & 0 & - & - & - & - & - \\
R2 - Nabileque & - & - & 21.5 & - & - & - \\
R3 - Nhecolândia & - & 0 & - & 79.2 & 68 & 5.8 \\
R4 - Nabileque & - & - & 100 & - & - & - \\
\hline
\end{tabular}




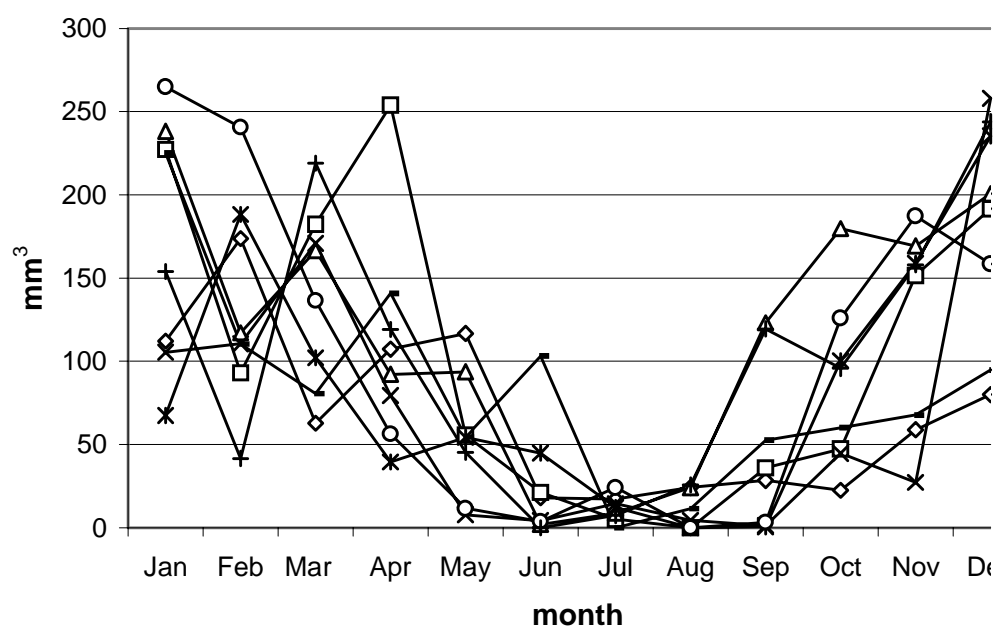

Monthly precipitation means from years 1990-1997 in the Pantanal of Nhecolândia sub-region, State of Mato Grosso do Sul (Balbina Soriano, Embrapa-Cpap, pers. commun.).

high prevalence found in the present study in the Nabileque sub-region (R2). This is possible because of the Pantanal of Paraguay sub-region is close to the Pantanal of Nabileque, and R3 is one of the nine places where outbreaks occurred in 1994 (Silva et al. 1995a).

T. evansi is in fact enzootic in the Pantanal and the present study showed an indication of enzootic instability in 1994 when outbreaks in horses from the Nhecolândia sub-region were reported. Studies on serodemes and VAT (variable antigenic type) populations of circulating strains, as well as seroprevalence in animals from neighbors sub-regions to Nhecolândia before 1994 should be made for a better understanding of the dynamics of this parasite in the region.

\section{ACKNOWLEDGEMENTS}

To Balbina Soriano for data on precipitation in the Nhecolândia. To Ernandes Ravaglia and Davina Santos for the technical assistance.

\section{REFERENCES}

Barros J 1959. Lembranças para os Meus Filhos e Descendentes, Empresa Gráfica Carioca, São Paulo, $92 \mathrm{pp}$.

Bejarano 1996. Estudio del Comportamiento de los Tábanos (Diptera, Tabanidae) en las Actividades Ganaderas, en General Saavedra, Santa Cruz, Bolivia, 1994/1995, Thesis, Facultad de Ciencias Agricolas, Universidad Autonoma Gabriel Moreno, Santa Cruz de la Sierra, Bolivia. 83pp.

Cadavid Garcia EA 1986. Estudo Técnico Econômico da Pecuária Bovina de Corte do Pantanal MatoGrossense, p.126-127. Embrapa/CPAP, doc. 4.

Dávila AMR, Silva RAMS, Jansen AM 1997. Dynamics of Trypanosoma evansi outbreaks in the Pantanal, Brazil, paper 136, First Internet Conference on
Salivarian Trypanosomes, FAO Animal Health and Production.

Franke CR, Greiner M, Mehlitz D 1994. Investigation on naturelly occuring Trypanosoma evansi infections in horses, cattle, dogs and capybaras (Hydrochaeris hydrochaeris) in Pantanal de Poconé (Mato Grosso, Brazil). Acta Trop 58: 159-169.

Gardiner PR 1989. Recent studies of the Biology of Trypanosoma vivax. Adv Parasitol 28: 229-317.

Gruvel J, Balis J 1965. La trypanosomiase à Trypanosoma evansi chez le dromadaire au Tchad et ses principaux vecteurs. Rev Élev Méd Vét Pays Trop 18: 435-439.

Hoare CA 1972. The Trypanosomes of Mammals. A Zoological Monograph, Blackwell Scientific Publications, Oxford and Edinburgh, 749 pp.

Klarmann-Osuna 1996 Determinación de la Presencia de Anticuerpos de Trypanosoma evansi en Equinos en el Departamento de Santa Cruz, Thesis, Universidad Autonoma Gabriel Rene Moreno, Santa Cruz de la Sierra, Bolivia, 72 pp.

Lohr KF, Pohlpark S, Srikitjakarn L, Thaboran P, Bettermann G, Staak C 1985. Trypanosoma evansi infection in buffaloes in North-East Thailand. I. Field investigations. Trop Anim Hlth Prod 17: 121-125.

Monzón CM 1986. Estudio serológico de equinos infectados com Trypanosoma equinum, utilizando la Hemaglutinación Indirecta com antígeno homólogo y de Trypanosoma cruzi. Rev Med Vet Buenos Aires 67: 293-297.

Monzón CM 1987. Inmunodiagnóstico de la tripanosomiasis equina o Mal de Caderas, mediante la prueba de inmunofluorescencia indirecta. Rev Med Vet Buenos Aires 68: 196-204.

Monzón CM, Colman OLR 1988. Estudio seroepidemiologico de la tripanosomiasis equina $(\mathrm{O} \mathrm{Mal}$ de Caderas) mediante la prueba de inmunofluorescencia indirecta en la provincia de Formosa (Argentina). Años 1983 a 1987. Arq Bras Med Vet 
Zoot 40: 279-285.

Nunes VLB, Oshiro ET 1990. Trypanosona (Trypanozoon) evansi in the coati from the Pantanal region of Mato Grosso do Sul State, Brazil. Trans $R$ Soc Trop Med Hyg 84: 692.

Nunes VLB, Oshiro ET, Dorval MEC, Espíndola MA, Cristaldo G, Da Rocha HC, Nunes AB 1995. Estudos epidemiológicos sobre leishmaniose tegumentar (LT) e Mal de Cadeiras no município de Corguinho, Mato Grosso do Sul - Estudo de reservatórios, 1992-1994. Brazil J Vet Parasitol 3: 29-35.

Santos SA, Sereno JRB, Mazza MCM, Mazza CA 1992. Origin of the Pantaneiro horse in Brazil. Arch Zootec 41: 371-381.

Seidl A, Moraes AS, Silva RAMS 1998. A financial analysis of treatment strategies for Trypanosoma evansi in the Brazilian Pantanal. Prev Vet Med 33:
219-234.

Silva RAMS, Barros ATM, Herrera HM 1995a. Trypanosomosis outbreaks due to Trypanosoma evansi in the Pantanal, Brazil. A preliminary approach on risk factors. Rev Élev Méd Vét Pays Trop 4: 315-319.

Silva RAMS, Arosemena NAE, Herrera HM, Sahib CA, Ferreira MSJ 1995b. Outbreak of trypanosomosis due to Trypanosoma evansi in horses of Pantanal Mato-grossense, Brazil. Vet Parasitol 60: 167-171.

Silva JSV, Seidl A, Moraes AS 1998. Evolução da Agropecuária no Pantanal Brasileiro, 1975-85. Embrapa/CPAP (in press).

Stevens JR, Nunes VL, Lanham SM, Oshiro ET 1989. Isoenzyme characterization of Trypanosoma evansi isolated from capybaras and dogs in Brazil. Acta Trop 46: 213-222. 